\title{
John Lakenheath's rearrangement of the archives of Bury St Edmunds Abbey
}

\author{
Andrew N.J. Dunning

\begin{abstract}
John Lakenheath (d. 1381) was a monk and administrator of the estates of Bury St Edmunds Abbey. He reorganized its archives in 1378-81, still in disorder after it was sacked by the townspeople in 1327. This culminated in the 'Lakenheath Registry' (London, British Library, Harley MS 743), an indexed directory of the Bury charters created in 1379-81. His preface to this book explains the archive's mode of operation, and is here printed for the first time and translated.
\end{abstract}

In 1327, the townspeople of Bury St Edmunds stormed the abbey, plundering its library and archives. ${ }^{1}$ Henry Kirkestede (c.1314-after 1378) restored its library; although his catalogue does not survive, the other remnants of his organizational vigour are among the most prominent sources for English libraries of the period. ${ }^{2}$ It is often overlooked that he worked in parallel with similar recovery efforts on the abbey's archives by Walter Pinchbeck and other monks, culminating in those of John Lakenheath (died 15 June 1381). ${ }^{3}$ He devised a register of the documents, which

${ }^{1}$ The abbey's narrative is Depredacio et combustio abbacie sancti Edmundi, British Library, Cotton MS Claudius A. XII, fols. 119r-129v, following the most recent foliation, three ahead of that in Memorials of St. Edmund's Abbey, ed. by Thomas Arnold, Rolls Series, 96, 3 vols (London: Eyre and Spottiswoode, 1890-1896), II, pp. 327-354. Rodney M. Thomson, The Archives of the Abbey of Bury St. Edmunds, Suffolk Records Society, 21 (Woodbridge, Suffolk: Boydell Press, 1980), pp. 20-21, attributes this text to Walter Pinchbeck. M.D. Lobel, The Borough of Bury St. Edmund's: A Study in the Government and Development of a Monastic Town (Oxford: Clarendon Press, 1935), pp. 142-55, and Robert S. Gottfried, Bury St. Edmunds and the Urban Crisis, 1290-1539 (Princeton, NJ: Princeton University Press, 1982), pp. 220-35, give an overview of the events of 1327-81.

2 Richard H. Rouse and Mary A. Rouse, Henry of Kirkestede. Catalogus de libris autenticis et apocrifis, Corpus of British Medieval Library Catalogues, 11 (London: British Library, 2004); Richard Sharpe, 'Reconstructing the Medieval Library of Bury St Edmunds Abbey: The Lost Catalogue of Henry of Kirkstead', in Bury St Edmunds: Medieval Art, Architecture, Archaeology, and Economy, ed. by Antonia Gransden, Conference Transactions, 20 (Leeds: British Archaeological Association, 1998), pp. 204-18.

${ }^{3}$ His work is summarized within the broader context of the abbey's archives by Thomson, pp. 23-31. 
survives as London, British Library, Harley MS 743, written in an unprofessional but tidy cursive script that is probably his own. ${ }^{4}$ Conflict was in the air again as he worked in 1379-81, and as a result of his administrative position he was beheaded in the town's marketplace during the Peasants' Revolt. In his preface to this book, explaining its mode of operation, John provides a glimpse into the mindset that prevailed at Bury at the time and into the mind of a medieval archivist.

John was presumably born in Lakenheath, Suffolk, a village just over $25 \mathrm{~km}$ from the abbey, and home to one of its manors. Few details of his life are known. It is likely the same figure who appears in 1369 as an attorney (atturnatus) of John Gernegan in the Blythburgh Priory cartulary. ${ }^{5}$ More ambiguously, a John de Lakenheath is found as a landholder in the late 1350s. ${ }^{6}$ He likely began his work on the abbey archives in 1378 or 1379. The register opens with a list of abbots up to the death of John of Brinkley on 31 December 1378 (fol. $53 \mathrm{r}-\mathrm{v}$ ), suggesting that he began work on it after this date.

There are also pressmarks on some surviving charters from the abbey, consisting of a letter and a number, presumably inspired by those of Henry Kirkestead. It has been suggested that John was also responsible for these. The most recent known charter marked in such a way is from 1378 , just as he seems to have started work on the registry. ${ }^{7}$ The cursive hand is similar to that found in much of John's register, though it is somewhat rounder, ${ }^{8}$ and some of the pressmarks are described as being in a

${ }^{4}$ Described in Thomson, no. 1283, pp. 5, 23-25, 30, 32, 129-130; G.R.C. Davis, Medieval Cartularies of Great Britain and Ireland, ed. by Claire Breay, Julian Harrison, and David M. Smith, 2nd edn (London: British Library, 2010), no. 97; provenance, Cyril Ernest Wright, Fontes Harleiani: A Study of the Sources of the Harleian Collection of Manuscripts Preserved in the Department of Manuscripts in the British Museum (London: British Museum, 1972), pp. 90, 316.

${ }^{5}$ British Library, Add. MS 40725, fol. 50v, summarized in Christopher Harper-Bill, Blythburgh Priory Cartulary, Suffolk Charters, 2-3, 2 vols (Woodbridge: Boydell \& Brewer, 1980-1981), no. 402.

${ }^{6}$ Mark Bailey, A Marginal Economy? East Anglian Breckland in the Later Middle Ages, Cambridge Studies in Medieval Life and Thought, 4th ser., 12 (Cambridge: Cambridge University Press, 1989), p. 64.

${ }^{7}$ Thomson, p. 32, presumably referring to no. 74, Bury St Edmunds, Suffolk Record Office, 449/2/27.

${ }^{8}$ Thomson, plate II (the image is swapped with that of plate III) reproduces the endorsement of Bury St Edmunds, Suffolk Record Office, 449/2/417. 
fifteenth-century hand. ${ }^{9}$ It is noteworthy that there are no traces of pressmarks on some of the abbey's most valuable charters, including some from the Anglo-Saxon period. They may have been introduced as identifiers for documents that did not have an obvious name; John refers to cartularies and rolls by their period. They continued to be used into the fifteenth century: Abbot William Curteys (d. 1446) refers to the pressmarks with corresponding locations. ${ }^{10}$

As an abbey administrator, John had a personal stake in ensuring that the archives were workable. According to the accounts of his death, he functioned as keeper of the barony (custos baronie), making him responsible for collecting dues and fines for the abbey's manors and making decisions on their rates. A surviving court roll from April 1381 shows him deciding the fate of the possessions forfeited by a felon of Chevington. ${ }^{11}$ This was at a time when many of the abbey's claims were open to challenge. ${ }^{12}$

John's administrative work made him a hated figure, and he was beheaded by a mob on 15 June 1381, during the Peasants' Revolt, as related by John Gosford:

Hanging the prior's head on a pillory, that whole cursing band came into the monastery, naming certain brothers, of whom they sought one before all the others, namely Walter Toddington; but when they could not find him, they sought another, namely the keeper of the barony. Although he could have fled from their hands, he refused to do so, declaring that he could not fall to a better cause than for the rights of his church, which he was always defending to the best of his ability, and therefore he wished to await the atonement of death for its sake, if it would drive their murderous hands from it. Some people from the village who hated him very much, pretending that they would be clean by his blood, arranged for wicked people from the region to capture, hold, and kill him. When they came into his cloister where he had been stationed, they shouted, 'Where is that betrayer?' He answered them, 'I am not a betrayer; but if you wish to have me, here I am.' They shouted, 'We have found the betrayer!' They carried him away from the cloister, and led him into the middle of the marketplace: leading him through the road, they dragged him along. They not only attacked him with blows, but inflicted many mortal wounds on him, so that he was nearly dead by the time he reached that place.

${ }^{9}$ E.g. Thomson, nos. 29-30.

${ }^{10}$ Rouse and Rouse, p. xlvii.

${ }^{11}$ Bury St Edmunds, Suffolk Record Office, E3/15.3/1.19(d), cited in Christopher Dyer, 'The Social and Economic Background to the Rural Revolt of 1381', in The English Rising of 1381, ed. by R. H. Hilton and T. H. Aston, Past and Present Publications (Cambridge: Cambridge University Press, 1984), pp. 9-42 (p. 14); Mark Bailey, The Decline of Serfdom in Late Medieval England: From Bondage to Freedom (Woodbridge, Suffolk: Boydell Press, 2014), pp. 179, 182.

${ }^{12}$ Lobel, pp. $139-40$ provides examples. 
There, the killer struck him seven times before he was able to cut off his head. They set it up on the pillory with the other heads. ${ }^{13}$

A similar story is told by Thomas Walsingham, ${ }^{14}$ whose account may be based on this one. He emphasizes the crowd's failure to recognize John, which must have seemed especially odd given that it had just travelled from Lakenheath. The events are stated more plainly in the depositions of John Wraw, who accused Thomas Langham of Bury of killing the monk. ${ }^{15}$

${ }^{13}$ Electio domini lohannis Tymwrith in abbatem, Cotton MS Claudius A. XII, fols. 135v-136r, printed in Arnold, III, p. 129, and Edgar Powell, The Rising in East Anglia in 1381 (Cambridge: University Press, 1896), p. 141:

Suspenso enim capite prioris in collistrigio tota illa maledicta comitiua uenit in monasterium nominans quosdam confratres quorum unum pre ceteris pecierunt luidelicet Walterum Totyngdon'/ quem cum inuenire non poterant pecierunt alium uidelicet custodem baronie, qui licet eorum manus potuit affugisse noluit tamen, asserens se non posse pociori causa occumbere quam pro iure sue ecclesie quam semper pro uiribus defensabat ideo uelle pro ea mortis supplicium expectare si funesta manus exegisset exigeret |fol. 136r| hoc ab eo. Quidam igitur de uilla eum nimium odientes similantes se esse mundos a sanguine eius procurabant malificos de patria ut eum caperent tenerent et occiderent. Qui cum aduenirent in claustro suo ubi fuerat constitutus clamabant ubi est ille proditor, quibus ipse respondit. Non sum ego proditor. si tamen uultis me habere eccine presens asto. Clamantes igitur inuenimus proditorem extraxerunt eum de claustro et perduxerunt ad medium fori et ducentes eum per uiam traxerunt eum hinc inde et non solum eum alapis ceciderunt sed ei plura mortis uulnera intulerunt ita quod fuit quasi exanimis antequam ad locum predictum deuenerunt deuenit in quo spiculator sepcies eum percussit priusquam amputare potuit eius caput, quod cum aliis capitibus super collistrigium posuerunt. [in the margin: a. J lakyn]

${ }^{14}$ John Taylor, Wendy R. Childs, and Leslie Watkiss, The St Albans Chronicle: The Chronica maiora of Thomas Walsingham, 2 vols (Oxford: Clarendon Press, 20032011), I, pp. 482-84; also translated in R.B. Dobson, The Peasants' Revolt of 1381, 2nd edn (London: Macmillan Press, 1983), pp. 245-46; David Preest and James G. Clark, The Chronica maiora of Thomas Walsingham, 1376-1422 (Woodbridge, Suffolk: Boydell Press, 2005), p. 143. Steven Justice, Writing and Rebellion: England in 1381, The New Historicism, 27 (Berkeley: University of California Press, 1994), p. 206, notes that Thomas reuses elements of the passage in describing the death of Simon Sudbury.

${ }^{15}$ Coram rege roll, 5 Richard II Easter, PRO, KB 27/484, Rex, m. 26, printed in André Réville and Charles Petit-Dutaillis, Le soulèvement des travailleurs d'Angleterre en 1381, Mémoires et documents publiés par la Société de l'École des chartes, 2 (Paris: 
In his preface to the register, John characterizes the archives as consisting of only a few remaining scraps, echoing the abbey's account of the events of $1327 .{ }^{16}$ This comes across as exaggerated today, but the damage to the archives was certainly considerable, and left the abbey unusually keen to make copies of its charters. ${ }^{17}$ The tone of his preface and the organization of the register echoes one produced in 1333 by Walter Pinchbeck. ${ }^{18}$ They both take a historical view to the documentation, but John is much more precise, only claiming to go back to the time of William the Conqueror rather than the Creation. Given this prevailing approach of working out of scarcity, Henry Kirkestede's work could also be considered in this light, his Catalogus furnishing in part a source of exemplars for new books. John does not aim to replace the abbey's documents with his register, but only to make it accessible.

The organizational scheme laid out in the preface still largely holds true for the manuscript, with the main register (beginning at fol. 52r) following an alphabetical index (fols. 4r-51r). There are many layers of production in the volume, with additions after John's death. The bulk of what survives was assembled under his watch: the Arabic foliation that he refers to in the preface runs from fol. 52 (originally 1) to fol. 259 (206), while fols. 260-75 (originally 208-23) are numbered in a contemporary but slightly smaller hand. Fols. 276-80 (originally 224-28) are filled

Picard, 1898), p. 178; translated in Dobson, p. 250; for Wraw's appeal, see Andrew Prescott, 'Judicial Records of the Rising of 1381 ' (unpublished Ph.D. thesis, Royal Holloway, University of London, 1984), p. 155.

${ }^{16}$ Cotton MS Claudius A. XII, fol. 120r, printed in Arnold, II, p. 330: 'Deinde claustrum ingressi cistulas id est caroles et armoriola fregerunt et libros ac omnia in eis inuenta similiter asportauerunt', 'Sacristiam fregerunt; cistas et omnia clausa diruperunt; aurum et argentum, libros, registra et uasa argentea sustulerunt et uinum ultra modum consumpserunt; registra et munimenta et cartas sacriste et unum equum pretio x librarum abduxerunt'.

${ }^{17}$ Kathryn A. Lowe, 'S 507 and the Abbey of Bury St Edmunds: Manuscript Preservation and Transmission in the Middle Ages', in Care and Conservation of Manuscripts 6: Proceedings of the Sixth International Seminar Held at the Royal Library, Copenhagen 19th-20th October 2000, ed. by Gillian Fellows-Jensen and Peter Springborg (Copenhagen: Museum Tusculanum Press, 2002), pp. 85-105.

${ }^{18}$ Cambridge, University Library, MS Ee.3.60, with Walter's preface at fol. 25r, printed in Francis Hervey, The Pinchbeck Register, 2 vols (Brighton: Farncombe's, 1925), I, pp. 57-58; Thomson, p. 124, translated at p. 21. 
with slightly later additions. ${ }^{19}$ The final product does not entirely correspond with the preface's scheme, likely cut short by death.

\section{The Preface to John Lakenheath's Register}

John's preface is preserved uniquely in Harley MS 743 , fol. $3 \mathrm{v}$. It was given the heading 'Re[gistrum] lohannis Lakynghethe' in a slightly later hand. In the text below, spelling and capitalization follow the original without modification, while punctuation follows its pattern, but has been silently emended for consistency. The paragraphing is editorial. Words in italics are underlined in the manuscript. ${ }^{20}$

\section{Text}

Quoniam monasterio nostro predonibus et igne destructo Registrisque Abbatum ac aliis munimentis sine restitucione furtiue sublatis ex tam habundanti segete euidenciarum ecclesie uix remanserant spice tenues post terga metencium Ego Frater lohannes de Lakyngheth' ex Registris diuersis kalendarium quoddam utcumque composui. In quo nomina quarumdan uillarum de quibus euidencias aliquas reperi secundum ordinem alphabeti seriatim digessi $\square$ quo posteris euidencie apercius pateant $\square$ quibus infra libertatem et extra iura regalia ceterasque libertates Abbas et Conuentus uendicatum securius ualeant $\square$ rogans lectorem beneuolencie pocius quam presumpcioni hoc opus notare. Et si quid in eo sibi gratum aut rite prolatum inuenitur eius gratie a quo omne bonum procedit. si quid autem $\mathrm{I}$ inconuenienter positum. mee magis impericie quam malicie deputet.

Desideranti igitur in hoc opusculo querenda facilius inuenire duo sunt quasi memoriter retinenda. Primum est quod folia kalendaris subscripti minime per figuras algorismi titulantur. Secundum est quod per hanc preposicionem Infra non debet aliquid queri extra istud Registrum set semper in eodem. ut uerbi gratia. Si queratur qui et quot fuerunt Abbates et inueniatur in kalendari habemus responcio pater infra folio primo uel secundo hoc est inteligendum quasi diceretur pater hic infra folio intitulato cum figuris algorismi presentis Registri.

19 The volume is collated $1^{2}$ (fols. i, 1; early modern flyleaves) $\mid 2^{2}$ (fols. 2-3) $\mid 3-8^{8}$

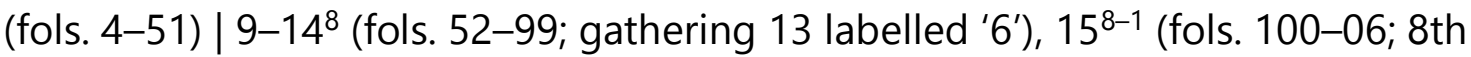
cancelled), $16-18^{8}$ (fols. 107-30) | $19^{2}$ (fols. 131-32; a later addition, with no medieval foliation) $\mid 20^{8}$ (fols. 133-40) $\mid 21^{8}$ (fols. 141-48) | 22-348 (fols. 149-252) $\mid 35^{8-1}$ (fols. 253-59; 8th cancelled) | $36^{8}$ (fols. 260-67), 378+1 (fols. 268-76; 9th added) | $38^{4}$ (fols. 277-80).

${ }^{20}$ Another translation of this text is in Thomson, pp. 23-24. 
In hoc autem kalendari talem intendo ordinem prosequi. Primo nomina uillarum inserere. Secundo quantum in uillis infrascriptis tempore Willelmi Conquestoris sanctus possedit Edmundus. Tercio que Abbas et Conuentus in eisdem uillis sibi et successoribus clamant habere. Quarto feoda militum et tenencium nomina. Quinto fines leuatos in Curia domini Regis tempore Sampsonis Abbatis. Sexto nomina eorum. qui homagia pro predictis feodis Abbatibus diuersis fecerunt. Septimo conuenciones inter Abbates et alios Magnates de regalibus in diuersis uillis habendum. Et si aliqua prenotata certis ex causis nequaquam perficiam acceptet lector uoluntatem pro facto $\mathrm{C}$ et dicat anime componentis misereatur omnipotens. Amen.

\section{Translation}

Seeing that our monastery was destroyed by robbers and fire, and the registers of the abbots and other muniments were stolen stealthily without return - the thin ears of corn behind the backs of the reapers had hardly remained from such an abundant harvest of evidence for the church - I, brother John Lakenheath, have somehow arranged from various registers a kind of calendar. In it, I have laid out in alphabetical order the names of certain manors about which I have discovered any documentary evidence. By this, the evidence may more openly be accessible to future generations, that within and beyond their liberty, the abbot and convent may have the power to proclaim their royal rights and other liberties more confidently. I ask the reader to annotate this work in kindness rather than presumption. And if he finds something brought to light in it that is agreeable to him or presented well, it is by the grace of him from whom every good comes forth; but if something is placed unfittingly, let it be ascribed rather to my ignorance than malice.

One desiring to find something more easily in this little work must keep two things in mind. The first is that the folios of the calendar written below are inscribed with small numerals in Arabic notation. The second is that through the preposition within, one should not seek something beyond this register, but always within it. For example, if one has asks who and how many abbots there were, and it may be found in the calendar, we have the response, Father, within the first folio or the second. This is to be understood as if it said: Father, here within the inscribed folio with the numerals in Arabic notation of the present register.

In this calendar, I aim to follow this order: first, to include the names of the manors; second, how much St Edmund held in these manors in the time of William the Conqueror; third, what the abbot and convent in these manors assert to have for themselves and their successors; fourth, knights' fees and the names of tenants; fifth, the payments raised in the court of the lord king in the time of Abbot Samson; sixth, the names of those who did homage for the aforesaid fees to various abbots; seventh, agreements between the abbots and other nobleman concerning the royal rights to be held in various manors. And if for certain reasons I am unable to 
complete something noted above, may the reader accept the will for the deed, and may he ask the omnipotent to have mercy on the soul of the compiler. Amen. 